\title{
Research on the Reform of Mathematics Talents Training Mode and Curriculum System in Local Normal University
}

\author{
Chen Yanfeng \\ College of mathematics, Tonghua Normal University \\ Jilin Province, China \\ wenjianke2007@163.com
}

\begin{abstract}
In order to improve the graduates quality of the local university in the new situation, according to the requirements of the employer and in order to meet the needs of the employer, the mathematics college of Tonghua Normal University, through in-depth practical social surveys, focus on the education concept and talents training objectives, to explore the reform of the original talents training program, talents training mode and curriculum system. Main content includes: clear training objectives, establish talents training mode, adjust and optimize curriculum system and establish safeguard measures and long-term echanism. Research characteristics includes: mathematics and applied mathematics major characteristics and characteristics statistics major.
\end{abstract}

Keywords-mathematics major; talents training mode; curriculum system; local normal university; mathematics college

\section{RESEARCH BACKGROUND}

Mathematics college of Tonghua Normal University, is one of the earliest colleges to be established. It began to recruit undergraduate students since 1987, received a bachelor's degree since 1991, recruited the first "Statistics" professional undergraduate in 2015. Mathematics college has became the training base that has two undergraduate professional in the southeast region of Jilin Province. Over the years, mathematics college has been formed its own concept, formed a unique style of education, conveying a large number of outstanding talents for Jilin Province. In the face of the severe and new employment situation for employer open recruitment examination graduates, we cultivate graduates facing deeply following pressure: the first, with the development of mathematics education, the employer (school) put forward new requirements for the talents, such as graduate students will make multimedia courseware, be proficient in a variety of classroom teaching art (master class, class skills), proficient in solving mathematical mock exam questions; the second, employment competition increasing with the same kind of inside and outside the province, normal colleges and similar between developed areas of similar colleges professional; the third, local normal universities compared with other key institutions and developed areas in colleges and universities, discipline comprehensive strength and discipline background disadvantage, lead to many employers (schools) have amount of skepticism on our graduates quality[1].
Under this background, how to effectively explore and construct a higher normal university's own characteristics, which is consistent with the university's own positioning, service field and school conditions, and has its own curriculum system, it is a significant issue for local normal universities. In 2015, the author declared "the innovative research on talents training mode based on the reform of mathematics curriculum reform (JY2015069) ", which was approved by Tonghua Normal University as "the higher education teaching reform research project". The theoretical research and the experiment reform have a strong pertinence, which has important practical significance to the reform of the talents training and the curriculum system.

\section{MAIN CONTENT}

\section{A. Clear Training Objectives}

Through analyzing the development trend of middle school mathematics education, the characteristics of local economic social development requirement of special talents in mathematics, this paper further clarifies the special attributes of discipline specialty and its requirements for talents cultivation. The local high teacher mathematics undergraduate, according to the students' personality quality, focus on training, two-way diversion. Strive to maximize the overall quality of undergraduate students in mathematics, improve the professional competitiveness[2].

\section{B. Establish Talents Training Mode}

In recent years, after a full demonstration analysis, mathematics and applied mathematics major has a strong new talents training model. From the 2012 grade, it starts to strengthen the teaching basic skills training and assessment, improve students' teaching skills. The college will implement the " $3+1$ " personnel training program from the 2013 grade, that is, study three years in school, graduation practice and graduation thesis work for one year, effectively protect the graduates with a solid professional knowledge, but also has a strong teaching ability and work experience[3]. The new training program fully embodies "the principle of people-oriented, comprehensively implement the principle of strengthening the foundation, strengthen the professional skills", and pay attention to the students' problems, analyze problems, 
solve problems and develop the skills of modern education.

\section{Adjust and Optimize Curriculum System}

Along with the reform of talents training mode, the college teaching activities should be carried out in every aspect, in the spirit of seeking a pragmatic, strict management, the principle of emphasizing the characteristics, and constantly revised and improved the training objectives and professional training program, in order to adapt to the basic education reform and social economic development needs.

For mathematics and applied mathematics major, we should increase the proportion of the practical teaching in mathematics education. In 2013, the training program was revised, and in the principle of "thick foundation, wide caliber, practice and innovation", the main course is divided into two major parts: the basic course and the core required course. The professional elective course is divided into three parts: the teaching direction, the basic mathematics and the applied mathematics.

For the statistics major, to increase the proportion of computer technology, statistial application courses and to improve the professional skills as the core of the practice teaching, strengthen the ability to enhance the statistial expertise as the core of the ability, then improve the quality of talents training[4].

\section{Establish Safeguard Measures and Long-term echanism}

1) Strengthen course construction, subject construction and specialty construction, teachers team construction.

To promote teaching materials, curriculum development, especially the construction and application of quality courses in promoting innovation for higher education, deepen reform in universities, and promote the application of modern technology, to achieve quality and efficiency of higher education. To encourage teachers to use modern teaching methods to organize teaching, teachers should be encouraged to declare the provincial, research teaching university education, all professional courses should record, lay a good foundation for the subsequent curriculum construction. Mathematics and applied mathematics professional courses all strive to be completed the excellent course in university, then construct 1-2 provincial quality courses, construct 2-3 statistics professional excellent courses. Actively promote the reform of teaching contents, teaching methods, teaching means and teaching evaluation methods, encourage senior teachers actively declare the provincial education teaching reform project, in the thirteen five period, strive to declare 5-8 school teaching reform project , 2-4 university teaching achievements award, strive to cultivate the provincial education reform projects and the provincial teaching achievement award[5].

Strengthen discipline construction, mathematics discipline is the traditional advantage discipline, it is the school's key discipline, we should take mathematics discipline construction as the center, the statistics discipline construction as a breakthrough, apply statistics theory, strengthen the basic theory research and teaching research. In terms of major construction, according to the basic education and social economic development needs of talents training and higher education development trend, combined with the development of the school development planning and mathematics college, according to the scale, structure, quality and efficiency principles, and strive to do well mathematics and applied mathematics major and statistics major.

The mathematics college insists on the peopleoriented, to improve the overall quality of teachers as the core, to cultivate and introduce high-level talents as the focus, form a higher degree of education, professional title and age structure is more reasonable, research ability, teaching level is relatively stable with outstanding talents reserve. However, there are still some problems in the construction of the teachers, which are as follows: the overall level of teachers needs to be further improved, and the training of young teachers is not enough. In view of the above problems, the mathematics college takes the following effective measures: the first is to implement young teacher tutorial system. For every new teacher, arrange one instructors to teach and guide young teachers, give full play to the role of mentoring teachers; the second is to encourage young teachers $\mathrm{PhD}$; middle-aged teachers and senior visiting scholars with short-term training mode, improve teaching level and scientific research; the third is to actively carry out academic communication. Invited 2-3 Jilin University, Northeast Normal University, Dalian Technology University and other famous professors to do the report, to open up vision field, to understand the latest developments in the frontier[6].

2) Carry out major reforms of the teaching content and teaching methods.

Teaching content. In the teaching content, we should pay more attention to the basic theory and basic skills, appropriately increase the number and depth of elective courses, understand the knowledge of the frontier areas of this profession, and use the mathematics discipline advantage to research and promote the teaching reform and improve teaching quality. The first is to optimize the curriculum, broaden the elective courses, set up three elective modules, a reasonable set of required courses; the second is to increase the number of foreign teacher education courses, broaden employment channels for students; the third is to pay attention to the practice teaching, increase teaching practice and graduation thesis credits, enhanced the students' practical ability, in order to carry out the students' basic teaching skills training and assessment; the fourth is the network teaching resources construction of provincial excellent course and excellent courses[7].

Teaching methods and teaching means. Relying on the provincial characteristics professional construction, actively carry out the reform of teaching methods and means. We often take the teaching and research unit for the organization to observe the teaching, according to the different teaching content uses the different teaching methods, uses the research type and the case type and so 
on[8]. For individual courses, such as mathematical modeling and mathematical software often use "problem driven", from the college students' Mathematics Modeling Contest questions, effectively mobilize the learning enthusiasm of students, improve learning ability. The professional teachers can combine the traditional teaching methods and modern educational technology, teaching courseware quality is higher, the teaching effect is obvious. In 2012, the "Application of mathematics software" and the paper "the application exploration of Mathematicas in differential geometry " were given the Jilin province education technology award.

3) Strengthen practical teaching, diversification, and improve the overall quality of the mathematics professional talents.

Practical teaching has the irreplaceable role in the cultivating students' comprehensive quality, intelligence and skills, so we put the practice teaching and theory teaching in the same position. Constructs a normal students practice teaching platform. A view is to firmly establish the educational concept; the second view refers to the education management trainee, classroom teaching practice; training refers to teaching practice, including microteaching training, textbook analysis and comprehensive ability training, teaching and training refer to the teaching practice and teacher training; the third research refers to the research and study of mathematical modeling and mathematical competition project problem,. Many practice shows that: the construction of practical teaching platform, highlighting the teacher training, training the students teaching ability, improve the overall quality of students[9].

These are reflected in the following aspects: professional talents cultivation mode, professional course system reform, professional skills practice, professional social effects, all mode construction are the new talents integration in local normal university.

\section{RESEARCH CHARACTERISTICS}

\section{A. Mathematics and Applied Mathematics Major}

Bilingual teaching to meet the future development needs of the students. According to the course characteristics, the ordinary differential equation in the teaching of English teaching materials, the Chinese teaching materials as a supplement, the main knowledge points of two organic integration, according to the actual students situation in the appropriate adjustment of the proportion of English Teaching (to ensure that the proportion of English is not less than 50\%). These both active classroom atmosphere, stimulate students' interest in learning, but also build foundation for the future to further study[10].

Implementing the competition to promote learning, training students' practical ability. College created the mathematical modeling course from 2000, at the same year, the team participated in the National Mathematical Modeling contest[11]. Through the competition, on the one hand, the students' imagination and creativity have been fully played, and the ability of students' theory with practice has been developed. On the other hand, it has aroused the enthusiasm and initiative of students' learning.

Implementing the academic tutor system to do indepth education of students. The college built four undergraduate tutorial system mode, namely the teachers to guide the students to learn, learn to learn, learn to do, guide students to participate in the training of teaching basic skills, improve students' teaching skill, guide students to carry out academic research activities, improve research ability. To guide the students to carry out scientific occupation career planning, and go into action. The development of the tutorial system, let the teacher go to the students, "one to one" to guide, strengthen the ideological and political education, and effectively improve the students' comprehensive quality and basic skills, the effect is good[12].

Developing a variety of activities to strengthen study style construction. Mathematics college launched the "three festival" (Tao Xingzhi Education Culture Festival, college students' employment festival, college students' science and technology festival), " two season" (freshman quarter and graduation season theme educational activities) and "one theme" (Yang Jingyu spirit education practice activity) working mode, focus on the cultivation of students' basic skills and comprehensive quality, efforts to promote the professionalization of teacher education, occupation, employment and enrollment entrance export driven training process, help students to set up a clear goal.

\section{B. Statistics Major}

Implementing competition to promote learning, improve the students' ability to solve practical problems. Pay more attention to the organization of data analysis and statistics modeling contest, using various competitions to promote the students to strengthen learning, master data application skills to enable students to succeed in the practice of training and competition experience, through competition winning to bring honor and achievement, resulting in psychological source of motivation for learning, cultivate good learning style. Students apply statistics knowledge to solve practical problems in the competition, so that cultivate the basic knowledge of learning, basic skills and ability, combine the knowledge and experience. To help students find a way from "initial state" to "target state" of the problem, so as to arouse the students' initiative and enthusiasm, especially to stimulate students' initiative in cognitive structure search can fill in the knowledge experience, a series of processing(the idea, concept, principle, proposition and so on), improve students' ability to solve practical problems[13].

Pay attention to practical teaching, cultivate the application type special talents. Statistics major has just enrollment, practical teaching needs to explore and innovate. Can be used to explore the case teaching, deepen practical teaching mode; combine theoretical course experiment, strengthen statistical practice teaching; pay attention to practice, improve students' practical experience; strengthen the application of statistics software, improve students' comprehensive ability and other forms of practical teaching, practical training 
students' ability to solve problems, continuously improve the professional ability and comprehensive quality, lay a solid foundation for training applied talents.

Carry out the cooperation between enterprises and enterprises to meet the needs of local economic development. local economic development requires a lot of advanced statistics talents with innovative and practical ability, and local enterprise cooperation is the best way to cultivate the complex and key labor of complex and key labor in various kinds of statistics work. The teaching mode based on school enterprise cooperation is the goal of enterprise need to cultivate high skilled applied talents, and to stick to school enterprise cooperation way, to create a more close to the real situation of enterprises, to cultivate students' independent collection of data, analysis of data, and put forward the application ability. In order to train local economic construction needs of the talents, we should carry out the overall optimization from many aspects, carry out the cooperation between enterprises and colleges, gradually form the major characteristics, and truly break out a new way of cultivating compound statistics talents.

\section{SOCIALEFFECTS}

Li Wenjing, Song Yu and other classmates published some quality papers at the Heilongjiang Science and Technology Information Journals, highlight the application of mathematics. In recent years, in the "higher education press" Cup National Undergraduate Mathematical Contest in modeling and the national mathematics contest for college students (in the preliminaries) won the national first prize, two prize and third-prize(TABLE 1), outstanding achievements in the school's teaching skills of interns outstanding in the competition. Students led five university students innovation training project in Jilin province, twenty-five research projects, completed one university student extracurricular training project in 2013, one undergraduate business plan competition cultivation project[14].
TABLE I. STATISTICAL TABLE OF MATHEMATICAL MODELING CONTEST IN RECENT FOUR YEARS

\begin{tabular}{|c|c|c|c|}
\hline year & level & Award grade & number \\
\hline \multirow{6}{*}{2012} & \multirow{2}{*}{$\begin{array}{l}\text { Jilin } \\
\text { competition }\end{array}$} & $\begin{array}{l}\text { the second award of Jilin province } \\
\text { competition }\end{array}$ & 3 \\
\hline & & $\begin{array}{l}\text { the third award of Jilin province } \\
\text { competition }\end{array}$ & 10 \\
\hline & \multirow{4}{*}{$\begin{array}{c}\text { national } \\
\text { competition }\end{array}$} & $\begin{array}{l}\text { the second award of national } \\
\text { competition } \\
\text { the first award of Jilin province } \\
\text { competition }\end{array}$ & 4 \\
\hline & & $\begin{array}{l}\text { the first award of Jilin province } \\
\text { competition }\end{array}$ & 2 \\
\hline & & $\begin{array}{l}\text { the second award of Jilin province } \\
\text { competition }\end{array}$ & 3 \\
\hline & & $\begin{array}{l}\text { the third award of Jilin province } \\
\text { competition }\end{array}$ & 4 \\
\hline \multirow{7}{*}{2013} & \multirow{3}{*}{$\begin{array}{l}\text { Jilin } \\
\text { competition }\end{array}$} & $\begin{array}{l}\text { the first award of Jilin province } \\
\text { competition }\end{array}$ & 5 \\
\hline & & $\begin{array}{l}\text { the second award of Jilin province } \\
\text { competition }\end{array}$ & 9 \\
\hline & & $\begin{array}{l}\text { the third award of Jilin province } \\
\text { competition }\end{array}$ & 2 \\
\hline & \multirow{4}{*}{$\begin{array}{l}\text { national } \\
\text { competition }\end{array}$} & $\begin{array}{l}\text { the second award of national } \\
\text { competition } \\
\text { the first award of Jilin province } \\
\text { competition }\end{array}$ & 2 \\
\hline & & $\begin{array}{l}\text { the first award of Jilin province } \\
\text { competition }\end{array}$ & 4 \\
\hline & & $\begin{array}{l}\text { the second award of Jilin province } \\
\text { competition }\end{array}$ & 10 \\
\hline & & $\begin{array}{l}\text { the third award of Jilin province } \\
\text { competition }\end{array}$ & 1 \\
\hline \multirow{6}{*}{2014} & \multirow{3}{*}{$\begin{array}{l}\text { Jilin } \\
\text { competition }\end{array}$} & $\begin{array}{l}\text { the first award of Jilin province } \\
\text { competition }\end{array}$ & 1 \\
\hline & & $\begin{array}{l}\text { the second award of Jilin province } \\
\text { competition }\end{array}$ & 15 \\
\hline & & $\begin{array}{l}\text { the third award of Jilin province } \\
\text { competition }\end{array}$ & 6 \\
\hline & \multirow{3}{*}{$\begin{array}{l}\text { national } \\
\text { competition }\end{array}$} & $\begin{array}{l}\text { the first award of Jilin province } \\
\text { competition }\end{array}$ & 3 \\
\hline & & $\begin{array}{l}\text { the second award of Jilin province } \\
\text { competition }\end{array}$ & 16 \\
\hline & & $\begin{array}{l}\text { the third award of Jilin province } \\
\text { competition }\end{array}$ & 4 \\
\hline \multirow{6}{*}{2015} & \multirow{3}{*}{$\begin{array}{l}\text { Jilin } \\
\text { competition }\end{array}$} & $\begin{array}{l}\text { the first award of Jilin province } \\
\text { competition }\end{array}$ & 5 \\
\hline & & $\begin{array}{l}\text { the second award of Jilin province } \\
\text { competition }\end{array}$ & 10 \\
\hline & & $\begin{array}{l}\text { the third award of Jilin province } \\
\text { competition }\end{array}$ & 5 \\
\hline & & $\begin{array}{l}\text { the first award of Jilin province } \\
\text { competition }\end{array}$ & 6 \\
\hline & $\begin{array}{c}\text { national } \\
\text { competition }\end{array}$ & $\begin{array}{l}\text { the second award of Jilin province } \\
\text { competition }\end{array}$ & 12 \\
\hline & & $\begin{array}{l}\text { the third award of Jilin province } \\
\text { competition }\end{array}$ & 2 \\
\hline
\end{tabular}

In recent years, project group teachers has achieved fruitful results in the teaching research, presided over twenty-three provincial research projects and university research projects. Published forty papers in "Heilongjiang High Education Research", "China Adult Education", "Modern Education Management", "Middle School Mathematics Teaching Reference", "Modern Primary and Secondary School Education" and other publications on the teaching research (Figure 1). Got one outstanding teaching achievement award in Jilin Province, won three provincial educational technology achievement awards. Project team have published more than 100 papers in 
System Science and Mathematics, Jilin University Journal, Journal of Zhejiang University, Science and Technology, Journal of East China Normal University, Control and Decision and others from 2012, which were indexed by EI, CSSCI, SCI, ISTP search more than thirty (Figure2). Presided over thirty projects of Provincial Science and
Technology Department, Provincial Department of Education Planning project. A number of results obtained by the provincial, municipal and above the scientific research award, scientific research to promote teaching effect is obvious.

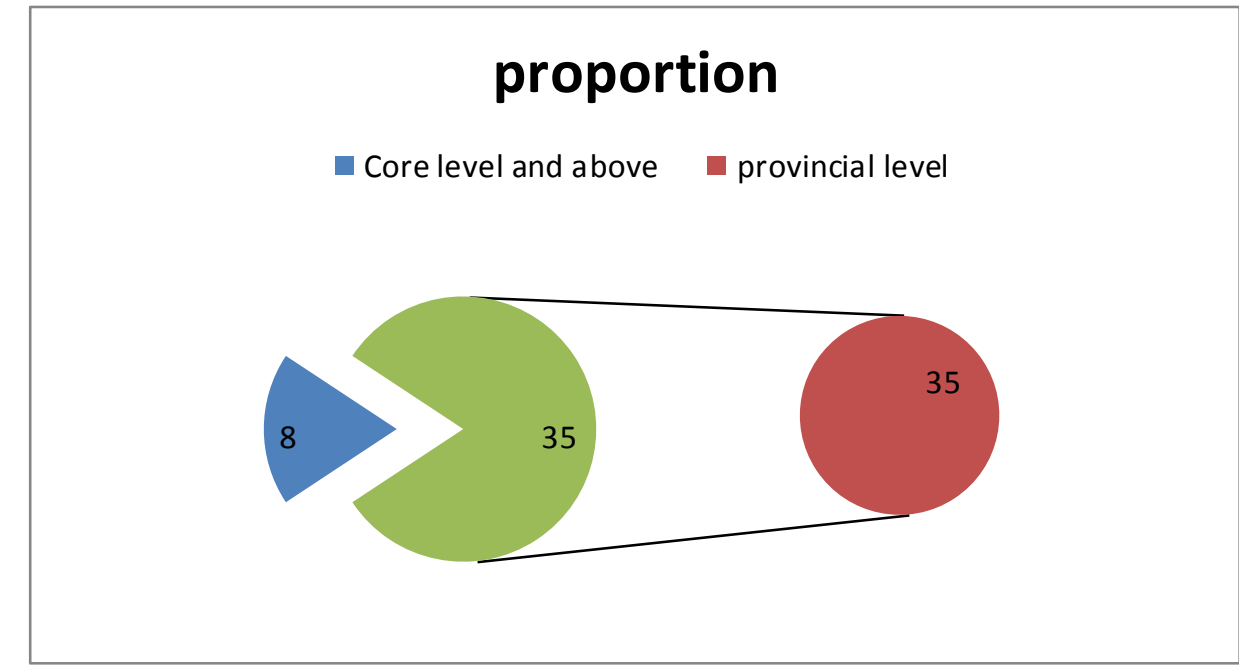

Figure 1. Statistics of education research papers published in recent four years

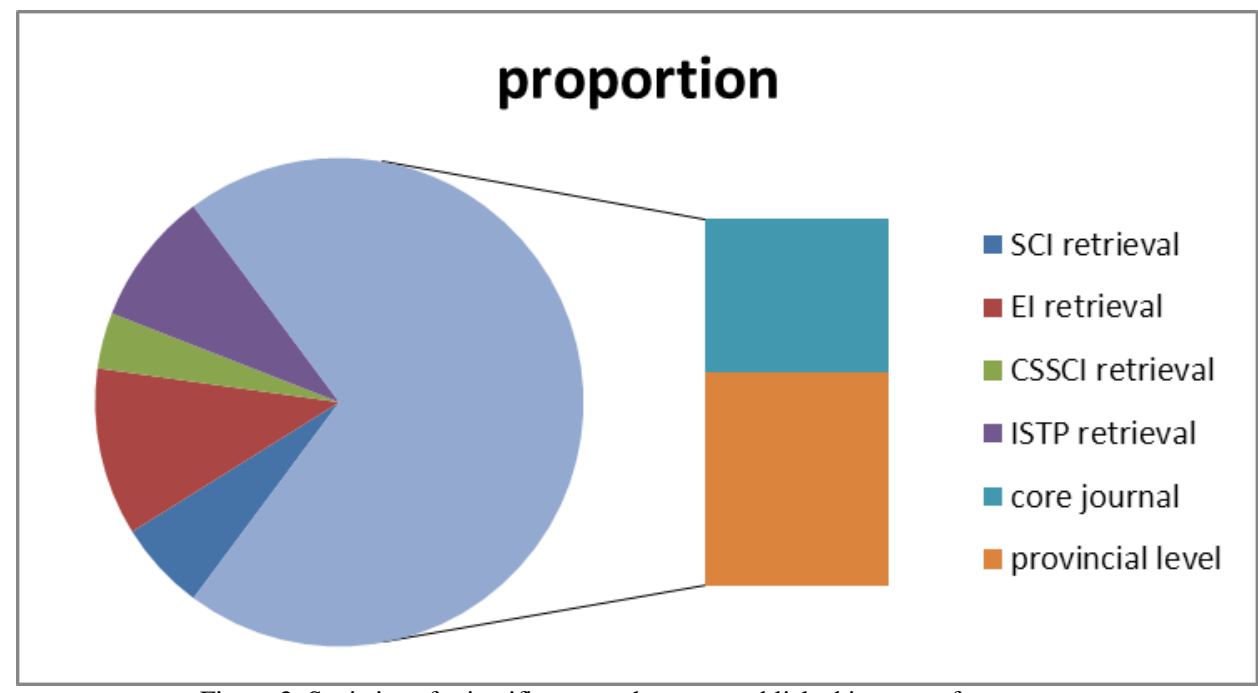

Figure 2. Statistics of scientific research papers published in recent four years

In social practice, labor, there is a plan that organized to participate in social practice and labor, has a research report, etc. Mathematics college also has many student organizations, such as, "Mathematical Modeling Association", "Middle School Mathematics Teaching Research", "Edge Drama" and "College Students' Practical Application Etiquette Agency" and so on, all organizations carry out regular activities, students actively participate in high[15].

\section{CONCLUSIONS}

Although there are some preliminary results in the innovation of talents training mode, but the time is short, the funds are few, the organization has been carried out, so there are still many problems, for example, the talents training standards and the curriculum content need to be further improved. Because of the change and the cognition of teachers' ideas are not in place, some data may not be able to reflect the experiment effect. In recent years, although the external environment has changed, but because of the poor foundation, the required funds, equipment, teachers, equipment, there are still more difficult. In the future, we will continue to carry out the research of this project, further explore the reform and innovation path of the local normal university's mathematical talents training mode and curriculum system.

\section{ACKNOWLEDGMENT}

This work was financially supported by the higher education teaching reform research project Tonghua Normal University "the innovative research on talents 
training mode based on the reform of mathematics curriculum reform (JY2015069)".

\section{REFERENCES}

[1] C.Y.Bin, "The research and practice on the reform of the talents training mode and curriculum system of national region higher normal university in new situation," Journal of Qiannan Nationalities Normal College, pp. 57-60,June 2013.

[2] H.Zhen,"Research on the mode of Higher Vocational statistics teaching based on the cooperation between schools and enterprises," Journal of Jilin Radio and TV University, pp. 4041, October 2013

[3] L.G.Qi, S.B.Ning, Research on the Training Mode of Innovative Applied Talents in Local Colleges and Universities, Shandong University Press, 2013.

[4] L.Qing, Talent Training Mode and Teaching Reform, Southwest Jiao Tong University Press, 2014.

[5] H.W.Qian, H.X.Ping, P.B.Hua, "Research on the teaching reform of market survey and forecast of High Vocational College,'Journal of Sichuan Economic Management College, pp.55-57,March 2015.

[6] P.W.Ling, T.Y.Jie, "Practice and thinking on provincial excellent course construction of mathematics analysis," Journal of Tonghua Normal University, pp. 27-28,June 2012.

[7] C.Yan, Z.Jian, "Research on higher mathematics teaching under the mode of training applied talents," Management and Technology of Small and Medium-sized Enterprises, pp. 264-265,Febrary 2015.
[8] F.Y.Yan, W.L.Jing, Zh.Jing. "The reform of university mathematics curriculum system based on the cultivation of innovative talents ," Journal of Cangzhou Normal University, pp. 116-119,January 2015.

[9] Z. X.Hong, M.Y.Xin, N.W.Su, Innovative Talents Training Mode Research, Economic Science Press, 2012.

[10] F.Yan, X.Ran, H.Y.Nan, "To explore assessment methods of higher mathematics course based on innovative talents training, ,Observation, pp. 83-85,May 2015.

[11] Y.X.Ling, L.Yan, F.H.Yun, "Study on the teaching based on the mathematical analysis goal of innovative talents cultivation ,' Chinese educational technology, pp. 124-125, May 2015.

[12] D.Wang, L.D.Hong, "Analysis of financial mathematics Professional curriculum setting and talents training quality,"Financial Theory and Teaching, pp. 89-92,March 2014.

[13] T.Jie. "The reform of higher mathematics teaching and the cultivation of applied talents ," Journal of Tongren University, pp. 181-183,April 2014.

[14] X.W.Dong, Z.H.Feng, the Training Mode of Law Major in Science and Engineering College, Harbin Institute of Technology Press, 2009.

[15] S.L.Feng. "Analysis on the reform of university mathematics curriculum based on applied talents cultivation " Journal of Lvliang Education College, pp. 79-81,March 2014. 